\title{
Research into the School-Enterprise Cooperation Model for the Practice-Oriented Teaching of Agricultural Universities and Colleges
}

\author{
Ying Zhang \\ Department of Teaching Affairs, \\ Jilin Agricultural University, \\ Changchun, China \\ Email: jlauzy@126.com
}

\begin{abstract}
The practice-oriented teaching of agricultural universities and colleges is an important approach for school-enterprise cooperation. However, there are a series of problems during the process. The author thinks that an effective school-enterprise cooperation model can be established to promote the practice-oriented teaching of agricultural universities and college by emphasizing on practices, intensifying school-enterprise cooperation efforts, cultivating school-enterprise cooperation talents and actively launching school-enterprise cooperation.
\end{abstract}

Keywords-agricultural universities and colleges; practice-oriented teaching; school-enterprise cooperation; model

\section{INTRODUCTION}

In the post-crisis era, China has entered a rapid transformation and upgrade period, thus calling for a large number of graduates with innovational, operational and entrepreneurial abilities. Social demands decide the development direction and motivation of universities and colleges. The serious lack of high-quality compound talents seriously restricts Chinese burgeoning economy. Agricultural universities and colleges should take the initiative to cultivate innovational talents to effectively promote and improve the cultivation of talents through school-enterprise cooperation. This is an important and strategic step for the development of agricultural universities and colleges.

\section{NECESSITY OF SCHOOL-ENTERPRISE COOPERATION FOR AGRICULTURAL UNIVERSITIES AND COLLEGES}

A. Necessity to develop the practical abilities of university and college students

Agricultural universities and colleges are an important part of China's general institutions of higher learning. The effective self-positioning and the clarification of self-development goals are of vital significance. As constructors and successors of Chinese agricultural modernization, agricultural universities and colleges should emphasize on enhancing the cultivation of their students' practical abilities during the teaching and scientific research process. Fundamentally speaking, China is still an agricultural country. Agriculture offers not only the substances for the survival of Chinese, but also raw materials for industrial development. Therefore, it is imperative for agricultural universities and colleges to adapt themselves to new situations, solve new problems and effectively improve their students' practical abilities ${ }^{[1]}$.

\section{B. Necessity to promote the employment of universities and college students}

With the increasing enrollment of universities and colleges, the absolute and relative number of universities and college students is soaring. However, university and college students are faced with more and more challenges to get a satisfying job. Apart from social and environment factors, the practical abilities of university and college students are also a great restriction. In universities and colleges, especially in agricultural ones, under the teaching background of emphasizing on theories while neglecting practices, students' practical abilities are obviously lacking, which can hardly meet the basic requirements of employment. To actively build an effective school-enterprise cooperation model can fundamentally solve the problem of inadequate practical abilities among university and college students, alleviate students' employment pressure, and strengthen and hone the teaching skills of the young teaching team.

C. Necessity to achieve the sustainable development of universities and colleges

At present, Chinese agricultural universities and colleges mainly follow the teaching model of centering on agricultural subjects and accommodating to the other subjects as well. However, an embarrassment is that they fail to do a good job of agricultural teaching, because they pay inadequate attention to students' practices. With the number of students participating in college and university entrance examinations continuously declining and the scale of universities and colleges continuously expanding, the enrolment of the general institutions of higher learning has a close bearing on the employment, development and future achievements of graduates. Therefore, to enhance the close cooperation between agricultural universities and colleges, and enterprises can contribute to not only the cultivation of high-quality talents, but also the sustainable development of universities and colleges. By doing so, universities and colleges can obtain a great driving force for their rapid development ${ }^{[2]}$. 


\section{PROBLEMS EXISTING IN SCHOOL-ENTERPRISE COOPERATION OF AGRICULTURAL UNIVERSITIES AND COLLEGES}

\section{A. Inadequate attention to practice-oriented teaching}

Currently, the link of practice-oriented teaching is missing in many Chinese agricultural universities and colleges, especially in some subjects closely related to agricultural production. For example, Agricultural Activities only focus on the infiltration of theories. As a result, students cannot effectively understand certain knowledge. Due to lack of practice-oriented teaching, students' practical abilities are inadequate. An important reason for lack of plans and goals for practice-oriented teaching is inadequate attention to practice-oriented teaching. Students are often free to choose their internship. This seems to be a respect for students' liberty. However, the lack of the regular practice link and the reliable practice bases impede the improvement of students' practical abilities.

\section{B. Inadequate school-enterprise cooperation efforts}

The school-enterprise cooperation in agricultural universities and colleges has not yet gone deep enough. When students take internship in enterprises, they are not treated as regular employees, so they cannot get strict management and training. As a result, it is hard for them to learn necessity skills and knowledge. Worse still, agricultural universities and colleges also do not regard cooperative enterprises as effective practice sites, so they loosen their management of students' internship in cooperation enterprises ${ }^{[3]}$. Actions and policies attractive to enterprises to cooperate with schools and active efforts to promote school-enterprise cooperation are inadequate. The school-enterprise joint construction should be enhanced. It is rare to find that schools and enterprises cooperate to jointly build practice bases, skill classrooms and textbooks, and train teachers, let alone new product R\&D centers and innovational contests. Enterprises and agricultural universities and colleges should learn from each other and give full play to each other's advantages, but, in fact, most of them fail to do so.

\section{Inadequate school-enterprise cooperation team building efforts}

School-enterprise cooperation calls for an excellent faculty team. It is impossible for agricultural universities and colleges to develop the whole faculty team into experts who know scientific research skills, and can lead students to practice in the field. However, many agricultural universities and colleges are eager to develop all teachers into versatile experts. In fact, the development model is quite superficial. It is necessary for teachers teaching theoretical knowledge to get involved with some practical knowledge, but it is impractical to develop them into Jack of all trades. As science and technology changes with each passing day, the faculty team should be personalized and professionalized. The above are reasons why agricultural universities and colleges fail to make full use of school-enterprise cooperation to hone their faculty team. Besides, enterprises' training of employees responsible for training the faculty team is inadequate. An excellent employee might not be an excellent teacher. Therefore, agricultural universities and colleges should effectively cooperate with enterprises in the training of these employees. The lack of the participation enthusiasm of highly-skilled employees in school-enterprise cooperation is also a critical reason for school's ineffective evaluation and monitoring of students' practices.

\section{Inadequate school-enterprise cooperation investment}

Schools' investment in school-enterprise cooperation is an issue of great concern. In current cooperation between enterprises and agricultural universities and colleges, the two sides fight for themselves. Enterprises often conduct small-scale cooperation with departments and subjects. The research sharing is inadequate, thus resulting in the low utilization rate of resources and the repeated construction of some basic projects. The root cause is the lack of a comprehensive and unified management mechanism. In terms of management, schools fail to invest adequate energy; in terms of hardware, schools fail to input adequate funds. Consequently, the teaching conditions are backward and the experimental level is poor. Under the condition, it is hard for school-enterprise cooperation to effectively develop students' practical abilities ${ }^{[4]}$.

\section{ESTABLISHMENT OF AN EFFECTIVE SCHOOL-ENTERPRISE COOPERATION MODEL FOR AGRICULTURAL UNIVERSITIES AND COLLEGES}

\section{A. Attach great importance to the practice link of school-enterprise cooperation}

Both leaders and grassroots staff should enhance their understanding of school-enterprise cooperation. On the one hand, the basic principles, ideas and goals of school-enterprise cooperation should be formulated; on the other hand, relevant personnel should stick to a progressive development model of school-enterprise cooperation. Only in this way can school-enterprise cooperation be systemized, optimized and standardized. Schools and enterprises should jointly develop or adopt the joint-stock cooperation system or even school-institution cooperation model. Attention should be paid to students' development of the scientific research abilities and improvement of their practical abilities during research and learning. School-enterprise cooperation should not only achieve mutual benefits, but also ensure students to get practices.

\section{B. Actively explore multi-model school-enterprise cooperation}

The current school-enterprise cooperation is still a simple or superficial cooperation. An effective 
school-enterprise cooperation model should meet every party's demands. In other words, enterprises should obtain their desired new concepts and new techniques; while schools can cultivate excellent talents through school-enterprise cooperation and get support for their practice-oriented teaching activities. The school-enterprise cooperation model can be a joint-development mode or a joint-stock cooperation model. The cooperation can be between schools and enterprises, schools and other institutions or even schools and individuals. The cooperation content can be the export of techniques or capitals. No matter which school-enterprise cooperation is adopted, the ultimate goal is to effectively develop students' practical abilities ${ }^{[5]}$.

\section{Effectively bring up school-enterprise cooperation talents}

Talents are a critical element in modern times. To actively build an excellent teaching team is a breakthrough for school-enterprise cooperation of agricultural universities and colleges. The promotion of the faculty team building can contribute to the improvement of teachers' scientific research qualities, innovational ability and social practice ability, and create favorable conditions to develop versatile graduates. Moreover, schools should help enterprises' talents to improve their teaching ability, which can, in turn, improve students' practical abilities; equip enterprises' technicians with the latest techniques and concepts so as to develop a high-quality teaching team of enterprises. Excellent school-enterprise cooperation talents can serve as a bridge and bondage for school-enterprise cooperation.

\section{Increase school-enterprise investment}

Agricultural universities and colleges should intimate their cooperation with enterprises, expand the scope of school-enterprise cooperation, give full play to their advantages in terms of techniques, information and talents; actively negotiate with enterprises and regard school-enterprise cooperation as a strategic deployment; input adequate capitals and devices; improve the practice-oriented teaching level and the teaching environment. Only in this way can agricultural universities and colleges effectively improve their students' practical abilities.

\section{REFERENCES}

[1] Liu Jia. Linkage Mechanism of Cooperation between School and Enterprises[J].Science and Technology Management Research,2011(7):87-90.

[2] Chen Ying. An Investigation of College-Enterprise Cooperation Model for Application-oriented Colleges and Universities[J]Application-oriented Colleges and Universities,2009(6):42-48.

[3] Wang Fang.The Analysis and Research on the University-Industry Collaborative Mode of Higher Vocational Colleges[J]. Research in Higher Education of Engineering,2012(4):121-125.

[4] Zuo Jiaqi. An Exploration into the College-Enterprise Cooperation Mechanism Under the Model of'Triple Convergence"[J].Research in Higher Education of Engineering,2010(3):126-130.

[5] Wang Xiaobo.Study on Encompassing Interest Mechanism of School-enterprise Cooperation[J]. Experimental Technology and Management,2014(2):146-150. 